\title{
The Efficacy of Phytogenic Feed Additives in Poultry Production: A Review
}

\author{
Imoleayo Sarah Oladeji ${ }^{1, a, *}$; Muyiwa Adegbenro ${ }^{1, b}$, Innocent Bamidele Osho $^{1, c}$, Olumuyiwa Joseph Olarotimi ${ }^{1, d}$ \\ ${ }^{I}$ Department of Animal Production and Health, The Federal University of Technology, Akure, Nigeria \\ ${ }^{*}$ Corresponding author
}

\begin{tabular}{l|l}
\hline A R T I C L E I N F O & A B S T R A C T \\
Review Article & $\begin{array}{l}\text { Over the years, the growing concerns about the negative impact of anti-microbial growth promoters } \\
\text { has triggered researches into the use of phytogenic feed additives in poultry production in order to } \\
\text { ascertain better performance of birds as well as safety in the food chain. Phytogenic feed additives } \\
\text { are compound derived from varieties of plants, its parts, extracts and essential oils which possess } \\
\text { active substances that are of significant importance. Some of its functions include anti-microbial and } \\
\text { anti-oxidative effects on the poultry feeds and carcass as well as enhancement of flavour of feeds. } \\
\text { Despite the beneficial influences of PFAs, numerous controversial issues have emerged on the } \\
\text { appropriate dosage to be used in poultry production. This may be due to the differences in edaphic } \\
\text { and climatic actions on plants available in various part of the world and stage of harvesting of plants } \\
\text { which makes standardizing inclusion levels of phytogenic feed additives in poultry diet seemingly } \\
\text { difficult. However, it is crystal clear that phytogenic feed additives qualify as a better substitute to } \\
\text { anti-microbial growth promoters as it is safe and ecologically friendly. }\end{array}$ \\
$\begin{array}{l}\text { Keywords: } \\
\text { Anti-microbial growth promoter }\end{array}$ \\
$\begin{array}{l}\text { Feed } \\
\text { Phytogenic feed additive }\end{array}$
\end{tabular}

Phytogenic feed additive

Poultry

Safe

\section{Introduction}

There is no doubt that the productivity of animals in Nigeria and the world at large needs to be improved upon due to the rising demand for animals' products and its byproducts. Therefore, the use of feeds as well as additives that are safe and of high nutritive quality is very crucial for optimum performance of livestock (Omenka and Anyasor, 2010). However, the use of new technologies in the production of some feed additives used in livestock feeds has been questioned due to the challenges it poses on food security. In numerous countries Nigeria inclusive, the use of antibiotics as growth promoters in the poultry industry has declined due to consumer's preference (Adedoyin et al., 2017), the deleterious effects of some of the synthetic feed additives on livestock and consumer health and the exorbitant prices of the commercial premixes (Adegbenro, 2015) and anti-microbial growth promoters (AGPs). Hence, these have led to the promotion of phytogenic feed additives (PFAs) in poultry diets as it is economical and has no residual effect on man when properly administered. Thus, the focus of this review paper is cantered on the efficacy of phytogenic feed additives in poultry production.

\section{Benefits of Phytogenic feed additives}

Generally, phytogenic feed additives contribute to the nutrient requirements of the animals as some of them are perfect substitutes for poultry premixes, act as antibiotics and antioxidants in vivo as well as in feed (Suganya et al., 2016). Some benefits of PFAs are:

Anti-Oxidative Functions of Phytogenic Feed Additives

The antioxidant properties of PFAs on the feed as well as poultry products cannot be overemphasized. It delays and inhibits lipid oxidation, reduces or minimizes rancidity of animal feeds, retard the formation of toxic oxidation products and help maintain the nutritional quality of the feed (Muanda et al., 2011). Several researchers have reported the antioxidant properties of herbs and spices such as mint, thyme and oregano. The anti-oxidative activities of the mint are attributed to the presence of phenolic terpenes and large amounts of monoterpenes, thymol and carvacrol in thyme and oregano (Rahim et al., 2011). The presence of sulphur constituents in garlic and onion has been reported not only to lower lipid effects but inhibit oxidation of low-density lipoproteins in poultry (Ahmed and Bassuony, 2009). Onibi et al. (2009) reported the 
oxidative stability of refrigerated broiler chicken meat of broilers fed high level supplementary raw garlic in broiler diet $(5000 \mathrm{mg} / \mathrm{kg})$ as well as the oxidation retardation function of thyme (Thymus vulgaris) when its dried leaves were added to either fresh or cooked refrigerated broiler chicken.

\section{Anti-microbial Functions}

PFAs are well known for their anti-microbial effects against pathogens. Studies by Ayachi et al. (2009) revealed the in-vitro effect of some extracts of berries, dates and thyme against E. coli and Salmonella isolates from chicken. Thyme was observed to be effective against Salmonella as well as against fungi such as Candida albicans due to the presence of the active compound: thymol and carvacrol. Likewise, walnut leaves (Juglandaceae) have been found to enhance the growth of chickens and reduce the proliferation of Clostridium perfrengens in them (Mathis et al., 2007). Hence, combining several chemically compatible PFAs will makes it more effective against several types of pathogenic organisms.

PFA solutions cleanse the digestive tract of birds which is very useful in diseases prevention in poultry as well as against some chicken parasites especially coccidia (Eimeria spp) (Arczewska-Wlosek and Swiatkiewicz, 2012). Tumeric has also been found to possess anti-tumoral activities aside from its antioxidant and anti-inflammatory properties as supplementation of feed with $1 \%$ turmeric spice according to Alloui et al. (2014) improves weight gain, reduces intestinal lesions and oocyst excretion in infected chicken with Eimeria maxima. Pepper (Piper guineense) extracts at the dose of $100 \mathrm{mg} / \mathrm{kg}$ body weight administered to the drinking water of the chickens acts as prophylaxis and boost the immunity of chickens (Osho et al., 2016). In addition, Onibi and Osho (2007) reported diminution in the bacterial load of refrigerated fresh and cooked meat of broiler chicken fed with diet containing Hibiscus sabdariffa calyces thereby improving the microbial carcass hygiene and the preservation qualities of meat.

\section{Palatability and Digestive Action}

Some PFAs improve the taste, palatability and acceptability of feed to poultry which help to promote their performances. Numerous PFAs exert beneficial actions on the gastrointestinal tract such as spasmolytic and laxative or against flatulence. Cinnamon extract, thyme and clove stimulate the digestive secretions of bile, mucus, saliva and improvement of enzymes activities which are of great nutritional interest (Platel and Srinivasan, 2004). Also, some oils extracted from plants positively influenced the activity of trypsin and amylase in chickens and has stimulatory effect on intestinal mucus in chickens to maintain an equilibrium in the microbes present in their gut (Jamroz et al., 2006).

Production Performances of Broiler Chicken Fed Phytogenic Feed Additives

PFAs enhance substantial improvement in the production performances of poultry in terms of weight gain and feed conversion ratio of chicken. This improvement was attributed to the high nutrient's availability due to changes in the intestinal ecosystem. Fenugreek seed (Trigonella foenum-graecum) supplementation improved significantly feed conversion ratio of broiler chickens which might be related to morphological changes in the gastrointestinal tissues (Mamoun et al. 2014) while the use of garlic (Allium sativum), thyme (Thymus vulgarus) and cornflower (Echinacea purpurea) as feed supplements exerted a wide range of beneficial effects on the production performance of broilers as studies carried out by Onibi et al. (2009) using raw garlic supplementation at the ratio of 5,000 to $500 \mathrm{mg} / \mathrm{kg}$ diet improved weight gain of broiler chickens. In addition, the use of composite leaf meal (Moringa oleifera, Ocinum gratissimum, Manihot esculenta, Telfaria occidentalis and Vernonia amygdalina) as a substitute for commercial broiler chicks' premix was reported to improve the heamatological indices of broiler chickens (Adegbenro et al., 2012). Broiler chicken given $10 \mathrm{~g}$ bitter leaf extract (Vernonia amygdalina) orally had improve weight gain and body maintenance alongside with anti-microbial property of the leaf extract compared to those given plain water and neoceryl (AGP) mixed water (Osho et al., 2014).

\section{Egg Production of Laying Birds on Phytogenic Feed} Additives

Numerous experiments had been carried out on the effects of various phytogenic additives on laying birds. Garlic (Allium sativa) had been revealed to possess properties which increased egg production, reduced cholesterol content of serum and yolk and improved immune response in layers (Azeke and Ekpo, 2009). Likewise, composite leaf meal (Moringa oleifera, Ocinum gratissimum, Manihot esculenta, Telfaria occidentalis and Vernonia amygdalina) as reported by Adegbenro (2015) disclosed that its use up to $5 \%$ act as appetite stimulant, facilitate healthy living and heighten the hen day production. Also, better weight gain, daily feed intake, feed conversion ratio, better hen day egg production, egg weight, yolk width and good albumen height was reported by Mary (2015) when $50 \mathrm{ml}$ and $100 \mathrm{ml}$ waterleaf mucilage was administered to birds. Dietary garlic powder supplementation caused positive differences in feed consumption, feed efficiency and egg production in birds over 12 weeks (Canogullari et al., 2010).

\section{Effect of Phytogenic Feed Additives on Internal and} External Egg Qualities

PFAs are commonly used as colourings for egg yolk. The effect of 1 and $2 \%$ feed supplementation with biomass of Chlorella on the concentration of total and individual carotenoids in egg yolk studied by Kotrbacek et al. (2013) revealed that there is a significant increase in the deposition of total carotenoids in egg yolk and consequently, its colour characteristics. Also, costmary (Tanacetum balsamita) inclusion at $1.5 \%$ and $2 \%$ to the diet of laying hens has a positive significant influence not only on the egg yolk colour but also on the overall production performance and blood indicators (lower triacylglycerols and cholesterol levels) of layers (Nobakht and Moghaddam, 2013). Adegbenro (2015) reported that composite leaf meal of five different leaf meals (Moringa oleifera, Ocinum gratissimum, Manihot esculenta, Telfaria occidentalis and Vernonia amygdalina) used to replace commercial premix 
in layers diet at a range of $2 \%-5 \%$ help to improve egg yolk colour and palatability of the diet. In addition, he affirmed that composite leaf meal inclusion in layer diets was instrumental in the reduction of the cholesterol content in egg yolk thereby acting as a potential hypocholesterolemic agent. Lower yolk and albumen $\mathrm{pH}$ were reported concerning the eggs collected from laying birds fed with composite leaf meal with the $\mathrm{pH}$ ranging from $7.0-9.0,6.4$ and $7.1-7.9$ for egg white, egg yolk and whole egg respectively. Likewise, the moisture contents for the egg white, egg yolk and whole egg are low enough to extend the shelf life of the egg powders in a humid environment compared to eggs collected from birds given diets supplemented with commercial layer premix. Hence, there is an increase in the values of the crude protein in the egg powder, egg yolk and whole egg as the levels of the composite leaf meal inclusion increases which may be due to the protein contents in the leaves. Relatively high ash content was also recorded. The improvement in the yolk colouration is attributed to Xanthophylls present in Moringa olifera (Etalem et al., 2013). Also, garlic, thyme, milfoil and fennel seed decreased trimethylaminuria (TMA) concentration which is responsible for fishy smell in yolk and possess remarkable antibacterial effects (Kirkpinar et al., 2011).

Furthermore, PFAs exert positive influence on shell thickness as it is important to reduce the percentage of cracked eggs and egg lost due to thin shells. Mary (2015) reported that the inclusion of $200 \mathrm{~g}$ of waterleaf mucilage to the drinking water of laying hen improves the shell thickness a great deal as well as shell weight. The improvement in shell thickness is because waterleaf contains $121 \mathrm{mg}$ calcium per $100 \mathrm{~g}$ edible portion. Also, Wubalem, (2014) reported that the inclusion of $5 \%$ Moringa olifera leaf to layers diet helped to improve eggshell thickness with shell thickness having the range of 0.29-0.38 while shape index was 75-80.

\section{Safety of Phytogenic Additives on Chicken Meat}

PFAs are natural products which have proven to be less toxic, free of residue and seemingly ideal feed additives in poultry production and livestock production as a whole. Several beneficial effects of PFAs have been recorded on stored meat quality based on their antioxidant properties in the terms of reduction of lipid oxidation, microbiological safety and quality upon meat storage in the raw or cooked stages through their anti-microbial and antioxidant functions (Onibi et al., 2009). The reduction of pathogens in the gut as well as the inhibition of pathogenic bacteria as a result of potential accumulation of PFA active components in metabolic tissues promote healthy gut environment which in turn contribute to a reduction of carcass contamination at slaughter (Puvaca et al., 2013). Hence, the European Food Safety Authority (EFSA) considered the administration of PFAs in livestock diet as one of the most effective ways of reducing the contamination of foodstuffs and the subsequent transmission of a number of food-borne diseases to man.

\section{Conclusion}

Considering the enormous benefits of phytogenic feed additives over antibiotics in poultry and its products as well as to humans when the products are consumed, PFAs are good substitutes for AGPs. They form natural constituent of feed, eco-friendly and retain no residual effect on chicken thereby making their meat safe for human consumption. Hence, they can be combined with other compounds such as prebiotics or probiotics to promote the performance of poultry production.

\section{References}

Adedoyin AA, Bamimore AI, Mosobalaje MA. 2017. Effect of red-hot pepper (Capsium annuum) in diets for broiler chickens. Proceedings $42^{\text {nd }}$ annual conference Nigeria society for Animal production. Pp 311 -313.

Adegbenro M. 2015. Characterization of some tropical leaves and their replacement values for commercial vitamin or mineral premix in poultry and swine diets. A PhD thesis submitted to the Department of Animal Production and Health, Federal University of Technology, Akure.

Adegbenro M, Ayeni A, Olowoyeye J, Bankole OM, Agbede JO, Onibi G, Aletor VA. 2012. Leaf composite mix as alternative premix to commercial premix in broiler finisher diets. Conference on International Research on Food security, Natural Resource Management and Rural Development, Tropentag Conference.

Ahmed AA, Bassuony NI. 2009. Adding natural juice of vegetables and fruitage to ruminant diets (B) nutrients utilization, microbial safety and immunity, effect of diets supplemented with lemon, onion and garlic juice fed to growing buffalo calves. World Journal of Agricultural Sciences, 5(4): 456-465.

Alloui MN, Amir A, Nadir A. 2014. Application of herbs and phytogenic feed additives in poultry production-A Review. Global Journal of Animal Scientific Research. Vol 2, 3.

Arczewska-Wlosek A, Swiatkiewicz S. 2012. The effect of a dietary herbal extract blend on the performance of broilers challenged with Eimeria oocysts. Journal of Animal Feed Science. 21: 133- 142 .

Ayachi A, Alloui N, Bennoune O, Yakhlef S, Daas Amiour W, Bouzdi S, Djemai Zoughlache K, Boudjellal K, Abdessemed H. 2009. Antibacterial activity of some fruits; berries and medicinal herb extracts against poultry strains of Salmonella. American Eurasian Journal of Agricultural Environmental Science. 6 (1): 12-15

Azeke MA, Ekpo KE. 2009. Egg yolk cholesterol lowering effects of garlic and tea. Journal of Medical Plants Research. Vol 3: 1113-1117.

Bolukbasi SC, Erhan MK. 2007. Effect of dietary thyme (Thymus vulgaris) on laying hens performance and Escherichia coli (E. coli) concentration in feces. International Journal of Natural Engineering Science, 2: 55-58.

Botsoglou NA, Grigoropoulou SH, Botsoglou E, Govaris A, Papageorgiou G. 2003. The effects of dietary oregano essential oil and [alpha]-tocopheryl acetate on lipid oxidation in raw and cooked turkey during refrigerated storage. Meat Science. 65: 1193-1200.

Canogullari S, Baylan M, Erdogan Z. 2010. The effects of dietary garlic powder on performance, egg yolk and serum cholesterol concentrations in laying quails. Czech Journal of Animal Science. 55: 286-293.

Etalem T, Getachew A, Mengistu U, Tadelle D. 2013. Moringa oleifera leaf meal as an alternative protein feed ingredient in broiler ration. International Journal of Poultry Science. 12: 289-297.

Frankic T, Salobir K, Salobir J. 2009. The comparison of in vivo antigenotoxic and antioxidative capacity of two propylene glycol extracts of Calendula officinalis (marigold) and vitamin E in young growing pigs. Journal of Animal Physiology and Animal Nutrition. 93: 688-694. 
Jamroz D, Wertelecki T, Houszka M, Kamel C. 2006. Influence of diet type on the inclusion of plant origin active substances on morphological and histochemical characteristics of the stomach and jejunum walls in chicken. Journal of Animal Physiology and Animal Nutrition. 90: 255-268.

Kirkpinar F, Unlu HB, Ozdemir G. 2011. Effects of oregano and garlic essential oils on performance, carcass, organ and blood characteristics and intestinal microflora of broilers. Livestock Science. 137: 219-225.

Kotrbacek V, Skrivan M, Kopecky J, Penkava O, Hudeckova P, Uhrikova L, Doubek J. 2013. Retention of carotenoids in egg yolks of laying hens supplemented with heterotrophic Chlorella. Czech Journal of Animal Science. 58: 193-200.

Mamoun T, Mukhtar AA, Tabidi MH. 2014. Effect of fenugreek seed powder on the performance, carcass characteristics and some blood serum attributes. Advance Research in Agriculture and Veterinary Science, 1: 6-11.

Mary S. 2015. Evaluation of quality and cholesterol level of eggs of laying hens placed on drinking water fortified with waterleaf (Talinum triangulae) mucilage. American scientific research journal for Engineering, Technology, and Sciences (ASRJETS). 13(1): 81-87

Mathis GF, Hofacre C, Scicutella N. 2007. Performance improvement with a feed added coated blend of essential oils, a coated blend of organic and inorganic acids with essential oils, or virginiamycin in broilers challenged with Clostridium perfringens. International Poultry Scientific Forum, Atlanta, Georgia.

Muanda F, Kone D, Dicko A, Soulimani R, Younos C. 2011. Phytochemical Composition and Antioxidant Capacity of Three Malian Medicinal Plant Parts. Evidence Based Complementary and Alternative Medicine, 21-28.

Nobakht A, Moghaddam M. 2013. The effects of different levels of costmary (Tanacetum balsamita) medicinal plant on performance, egg traits and blood biochemical parameters of laying hens. Iranian Journal of Applied Animal Science. 3: 307-312.

Omenka RO, Anyasor GN. 2010. Vegetable-based feed formulation on poultry meat quality. African Journal of Food, Agriculture Nutrition and Development Vol. 10 No 1.
Onibi GE, Osho IB. 2007. Oxidative stability and bacteriological assessment of meat from broiler chickens fed diet containing Hibiscus sabdariffa calyces. African Journal of Biotechnology, 6 (23): 2721 -2726.

Onibi GE, Oluwatoyin EA, Fajemisin AN, Ayodeji VA. 2009. Response of broiler chickens in terms of performance and meat quality to garlic supplementation. African Journal of Agricultural Research, 4(5): $511-517$.

Osho IB, Adebayo IA, Ajayi OI. 2016. Immunological evaluation of Anti-viral activity of Methanolic extract of piper guineense against New Castle disease in experimentally infected broiler chickens. International Journal of Molecular Veterinary Research, Vol 6 (2).

Osho IB, Akindahunsi A, Igbasan FA, Adekunle DJ. 2014. Effect of orally administered bitter leaf (Vernonia amygdalina) extract on the growth performance and haematological parameters of broiler chicken. Journal of Veterinary Medicine and Animal Health, 6(10): 251-256.

Platel K, Srinivasan K. 2004. Digestive stimulant action of spices: A myth or reality? Indian. Journal of Medical Research. 119: 167-179.

Puvaca N, Stanacev V, Glamocic J, Levic L, Peric L, Milic D. 2013. Beneficial effects of phytoadditives in broiler nutrition. World poultry science journal, 69: 27 -34.

Rahim A, Aghazadeh AM, Daneshyar M. 2011. Growth performance and some carcass characteristics in broiler chickens supplemented with Thymus extract (Thymus vulgaris) in drinking water. Journal of Animal Science. 7(11): 400-405.

Soltan MA, Shewita RS, El-Katcha MI. 2008. Effects of dietary anise seeds supplementation on growth performance, immune response, carcass traits and some blood parameters of broiler chickens. International Journal of Poultry Science. 7: 10781088.

Suganya T, Senthilkumar S, Deepa K, Muralidharan J, Gomathi G, Gobiraju S. 2016. Herbal feed additives in poultry. International Journal of Science, Environment. and Technology. Vol. 5, $1137-1145$. 